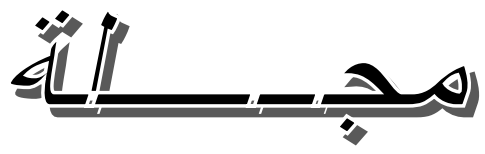

$$
\begin{aligned}
& \text { 界 } \\
& \text { (JSER) } \\
& \text { تصيسدر عـن } \\
& \text { مؤسسة التربية الخاصة والتأهيل } \\
& \text { (SERO) } \\
& \text { علمية - دورية - محكمة - متخصصة - معتمدة }
\end{aligned}
$$

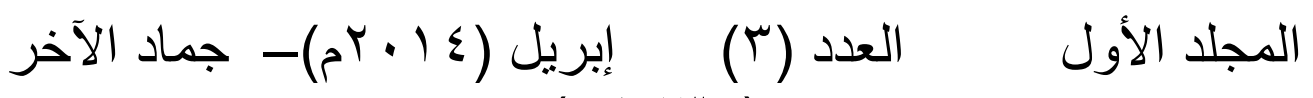

$$
\begin{aligned}
& (\rightarrow) \leqslant r 0)
\end{aligned}
$$




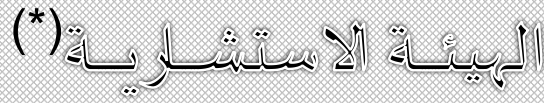

أ.د. عبد العزيز السيد الشخص

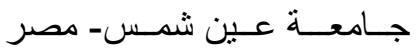
أ.د. عبد العزيز السرطــاوى الإقـات

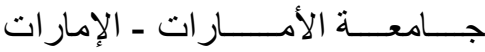

$$
\text { أ.د. فـاروق محمــد صـادق }
$$

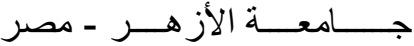

أ.د. فتحى مصطفى الزيات جـامعسـة المنصـــورة - مصر الزيات

$$
\text { أ.د. محمود عبد الحليم منسي }
$$

مقرر اللجنة العلمية لترقية الأساتذة والأساتذة

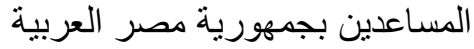

د. صـالــح عبداله هـارون

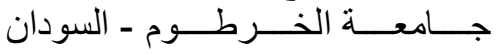

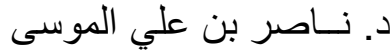

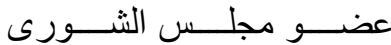

أمين عام التربية الخاصة بالسعودية سابقا

أ.د. هارفى رود جامعة شمال كولور ادو - الو لايات المتحدة الامريكية

\section{University of Northern Colorado}

أ.د. أحمـــ أحمـد عــــواد جامعة السلطان قابوس- سلطنة عمان

أ.د. زيدان أحمد السرطاوى جامعة الملك سعود ــ السعودية الرماوية

أ.د. جمــال محمد الخطيب الارديب الجـامعـة الأردنيـة ــ الأردن

أ.د. جميل محمود الصمادي الجـامعـة الأردنيـــة ــ الأردن

أ.د. خـــولـة أحمــد يحـي البحين جامعة الخليج العربى ــ البحرين

أ.د. طلعــت منصور غبربال

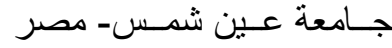

أ.د. عادل عبد الله محمد

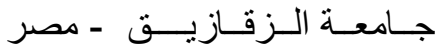

أ.د. عبد الله محمد الوابلي

جامعة الملك سعود ـ السعودية 


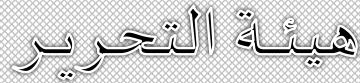

رئيس التحرير (

$$
\text { أ.د. عـلي عبدرب النحربرب }
$$

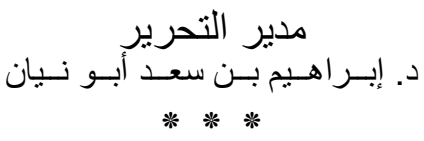
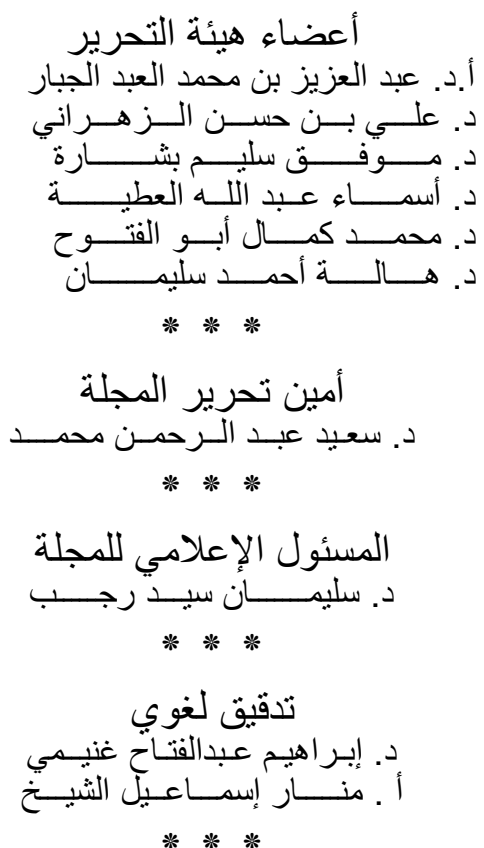

\section{سكرنير المجلة

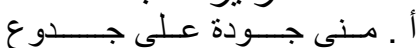 \\ journal@sero-eg.com}

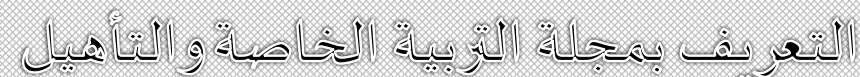

مجلة علمية دورية محكمة متخصصـة تصدـر عـن مؤسسـة التربيـة الخاصـة و التأهيـل Special Education and Rehabilitation Organization(SERO)

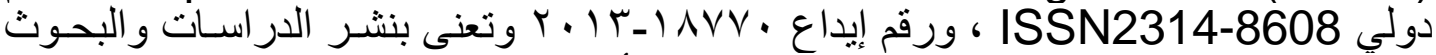

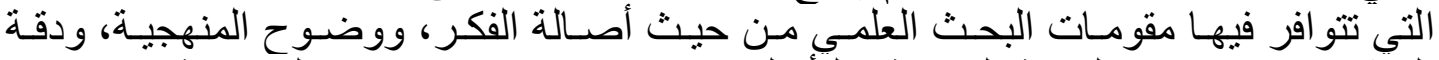

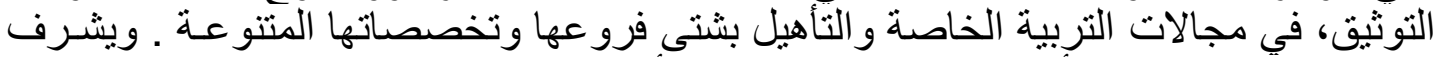

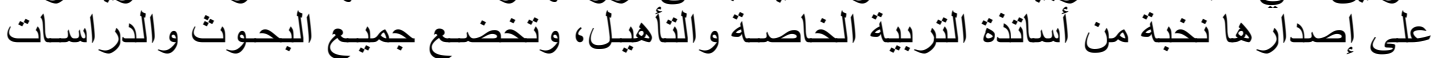

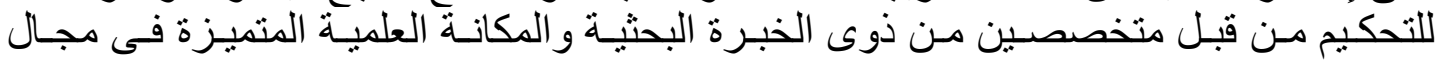




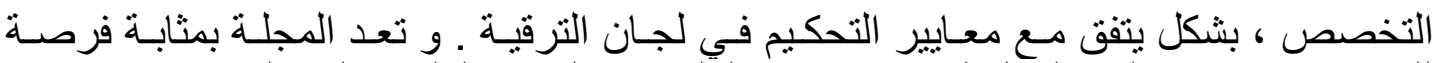

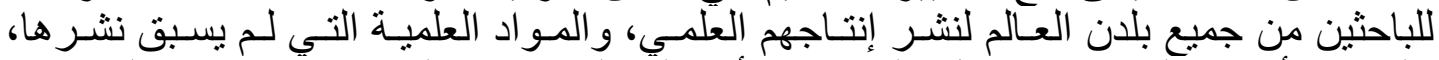

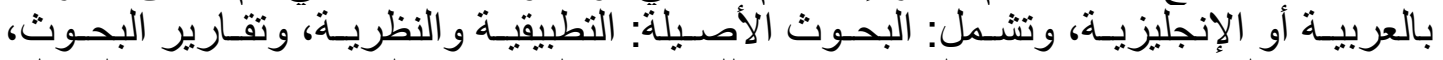

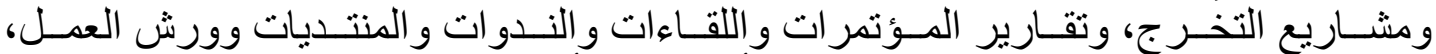

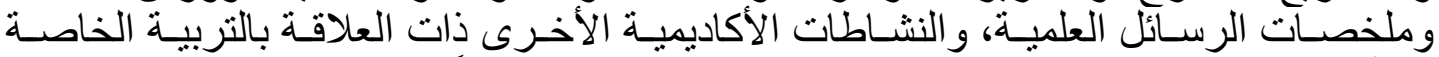
و التأهيل. كما ترحب المجلة بنشر عروض الكتب المنشورة حديثاً في مجال المجلة.

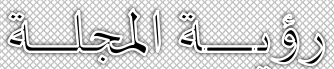

أن تكون مجلة رائدة، ومصنفة ضمن أشـهر المجـلات العلميـة، المعنبـة بنشـر البحـوث المحكمة في مجال التربية الخاصة، ونة والتأهيل في قو اعد البيانات العالمية.$$
\text { : }
$$

تسعى المجلة لتصبح مرجعاً علمياً للباحثين، ونشر البحوث المحكمة وفق معايير مهنيـة عالمية منميزة في التربية الخاصة ولة والتأهيل.

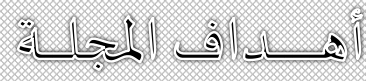

• إيجاد و عاء أكاديمي متخصصٍ في مجال التربية الخاصة و التأهيل.

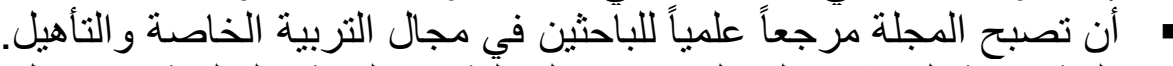

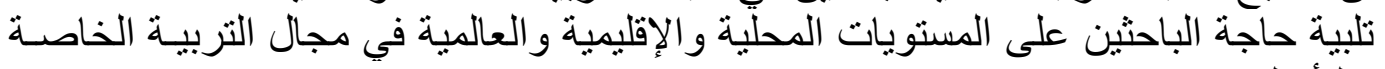

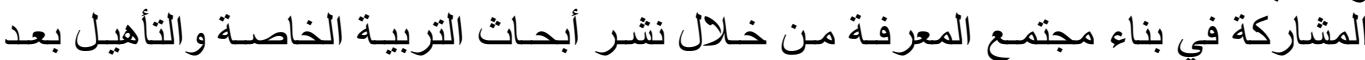

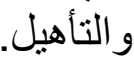
تحكيمها من الخبر اء في التخصص.

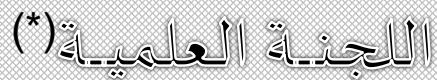

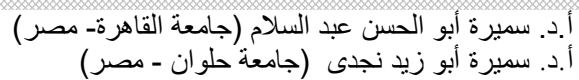

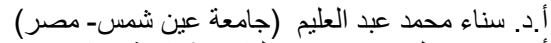

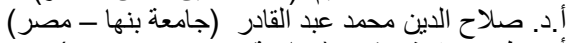

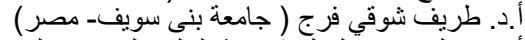

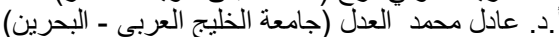

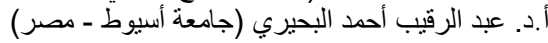

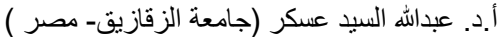

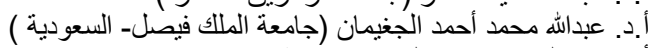

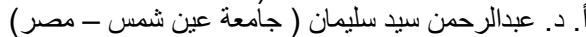

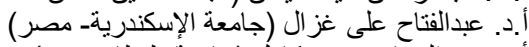

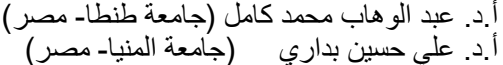

أ.د. أحد عده العزيز التميمى (جامعة الملك سعود- السعودية)

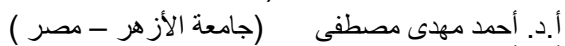
أ.أد. أحمد عبداله عباس (جامعة الكويت ـ الكويت)

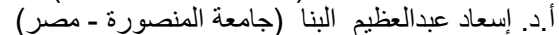

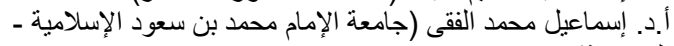
السعودية) أ.د. إسماعيل محمد بدر (جامعة بنها - مصر)

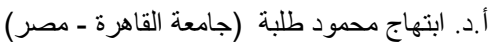
أ.د. إبر اهيم عبداله الزريقات (الجامعة الأردنية - الأردن)

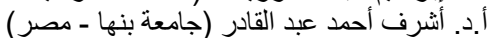

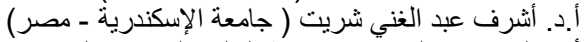
أ.د. السيد سعد الخميسي (جامعة الخليج العربي - البحرين)

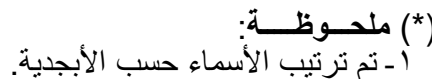

r- في ضوء التداخل و الارتباط الوثيق للبحوث و الدراسات التي تتناول فئات التربية الخاصة مع العديد من التخصصات مثل (علم

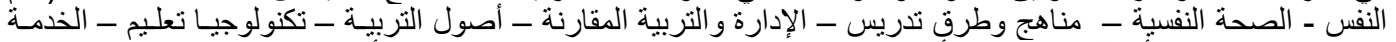

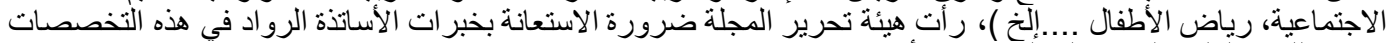


أ.د. علي مهذى كاظم ( جامعة السلطان قابوس - سلطنة عمان)

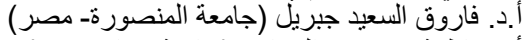

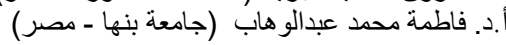

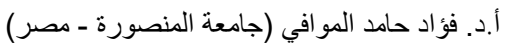
أ أد فيو لا فارس البيلاوى (جامع (جامعة الكويتـ الكويت)

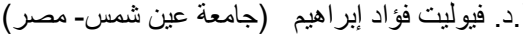

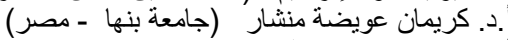

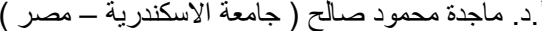
ا. أد. ماهر إسماعيل صبري (جامعة بنها - مصر ) أ.د. مجدي محمد الثحات (جامعة الملاتك فيصل ـ السعودية)

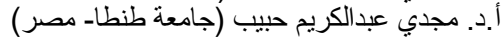

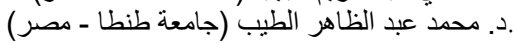

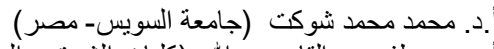

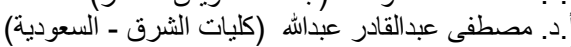
إ.د. معصومة سهيل المطيرى (جامعة الكويت ـ الكويت)

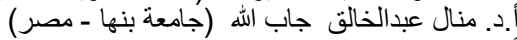

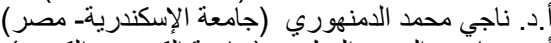

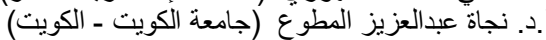

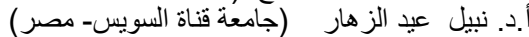

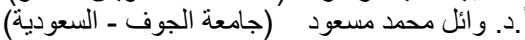
ا.د. إ. وفاء محمد كمال عبدالخالق (جامعة القاهرة - مصر ) أ.د. هثام عبد الرحمن الخولي (جامعة بنها - مصر )
أ.د. السيد عبدالحميد سليمان (جامعة حلوان - مصر )

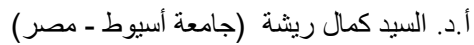

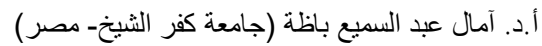

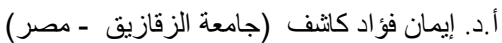
أ.د. بندر ناصر العتيبى (جامعة الملك سعود- السعودية)

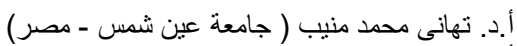
أ.د. جابر عبد الحميد جابر (جامعة القاهرة- مصر ) همرة)

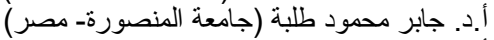
أ.د. حسن مصطفى عبد المعطي ( جامعة طيية- السعودية)

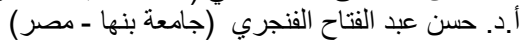

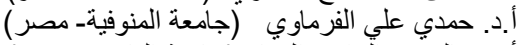

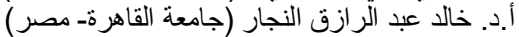
أ.د. راثد على السهل (جامعة الكويت الكارئ ـ الكويت) أ.د. راضى محمد الكبيسي (جامعة الأنبار - العراق) الثمان)

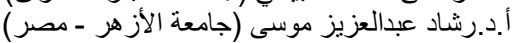

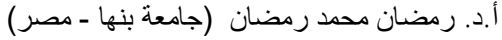

أ.د. زيد محمد البتال (جامعة الملك سعود- السعودية)

أ.د. زينب محمود شقير (جامعة الطائف ـ السعودية)

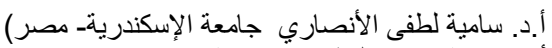

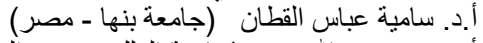

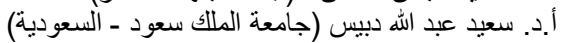

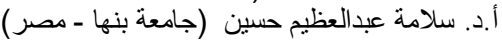

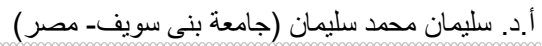

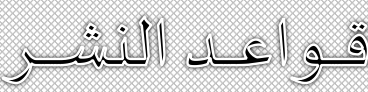

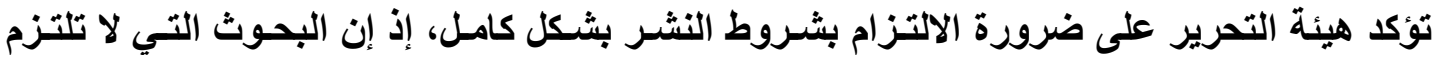

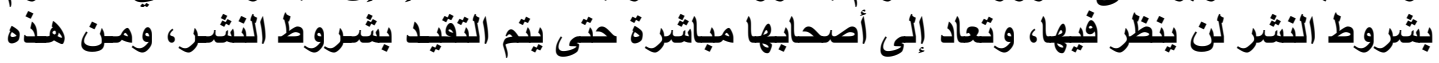

7- فوقرج الجداول في النص وترقم ترقيماً متسلسلاً وتكتب عناوينها.

V- تذكر الهوامش وملاحظات وتوضيحات الباحث في آخر الصفحة

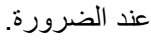

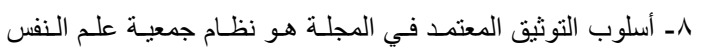
(American Psychological Association- APA-6th ED)

9- لهيئة التحريـر حف الفحص الأولـي للبحث، وتقريـر أهليته، أو رفضه للنشر.

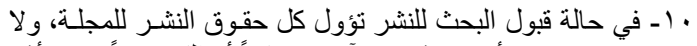

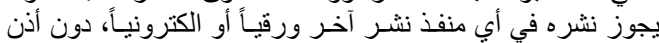
كتابي من رئيس هيئة التحرير.

11 - في حالة نشر البحث، بعطي الباحث نسخة من المجلة، وعدد (0) متسلّسلات من الدر اسة.

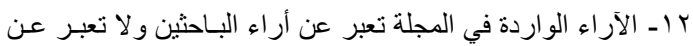

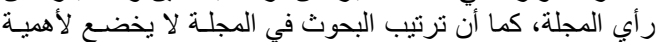

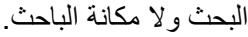

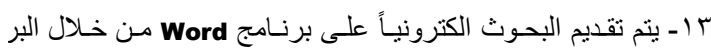

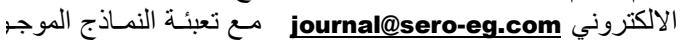
على موقع المجلة.

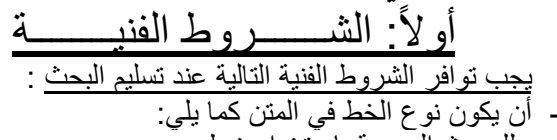

الثروط ما يلي: الثير:

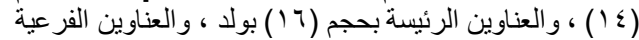

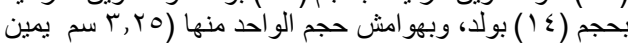

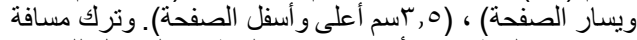
مفردة بين السطور ، و وأن يكون نوع الخط الخط في الجداول للبحوث

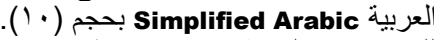

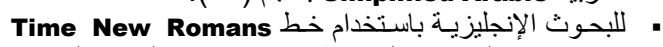

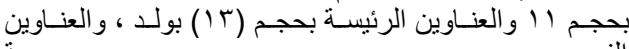

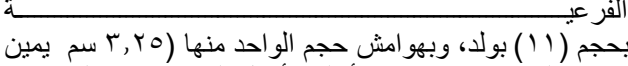

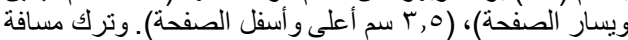

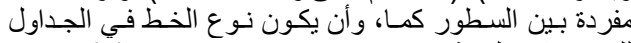

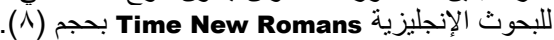

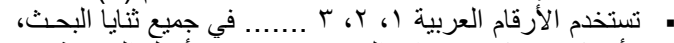
وأن يكون ترقيم صفحات البحث في منتصف أُسفل الصفحة. ثالبح.

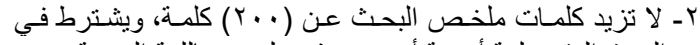

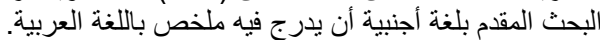

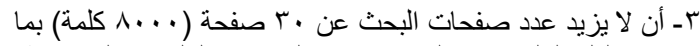

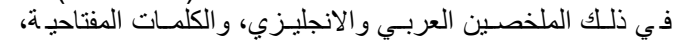

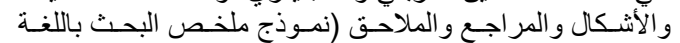
العربية واللغة الانجليزية). ع ـ أن يكتب عنـوان البحـث ، و واسـم الباحـث/ البـاحثين ، و الجامعـة/ 


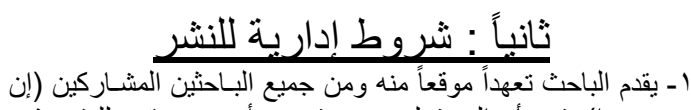

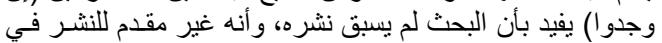

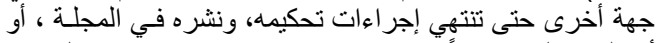
أن البحث ليس جزءأ من كتاب منشور (نموذج بيانـات الباحثب و التعهد بنشر بحث ). ك- لا يجوز نشر البحث أو أجزاء منه في مكان آخر، بعد إقرار نشره

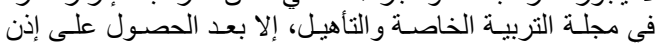
كتابي بذللك من رئيس التحرير.

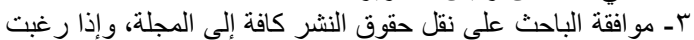

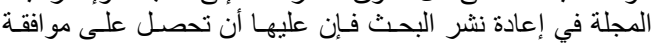

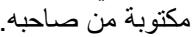

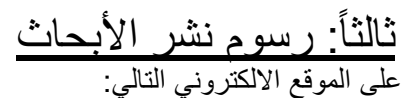
www.sero-eg.com

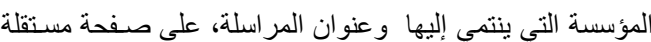

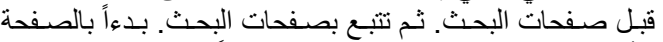

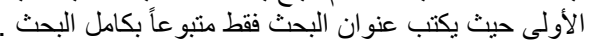

0ـ أن يتكون البحث من العناصر التالية: مقدمة ،مثكلة الدراسة وأسئلتها/ فرضية الدياتها، ثم أهدافها، ثم أهميـة

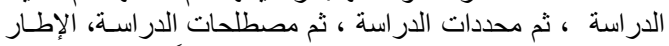

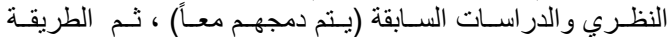

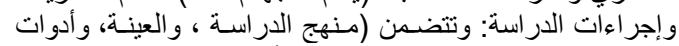

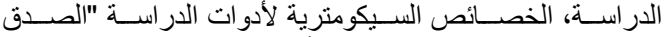

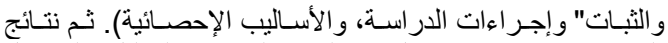

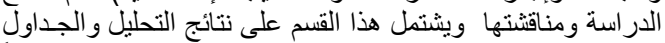

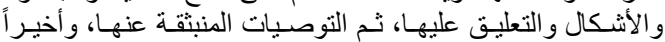

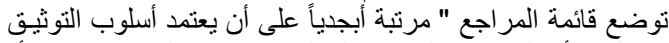

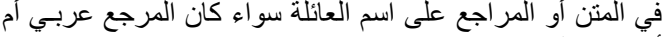

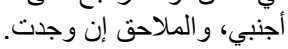

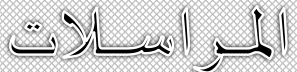

ترسل البحوث وجميع المر اسلات المتعلقة بالمجلة إلى البريد الاكتروني للمجلة: journal@sero-eg.com

• أو إلي رئيس هيئة تحرير مجلة التربية الخاصة و التأهيل: أ.د ـ علي عبدرب النبي حنفي

كلية التربية - جامعة الملك سعود/ جامعة بنها

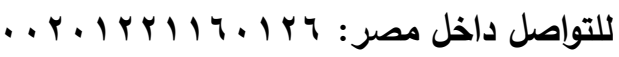

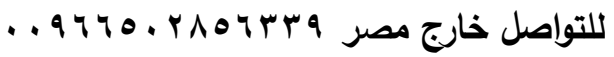

البريد الاكتروني:dralihanafe@hotmail.com

• لمتابعة الجديد في المجلة يرجى الدخول إلى الموقع الالكتروني للمجلة 


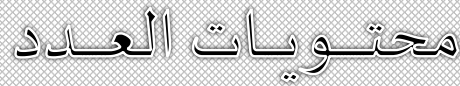

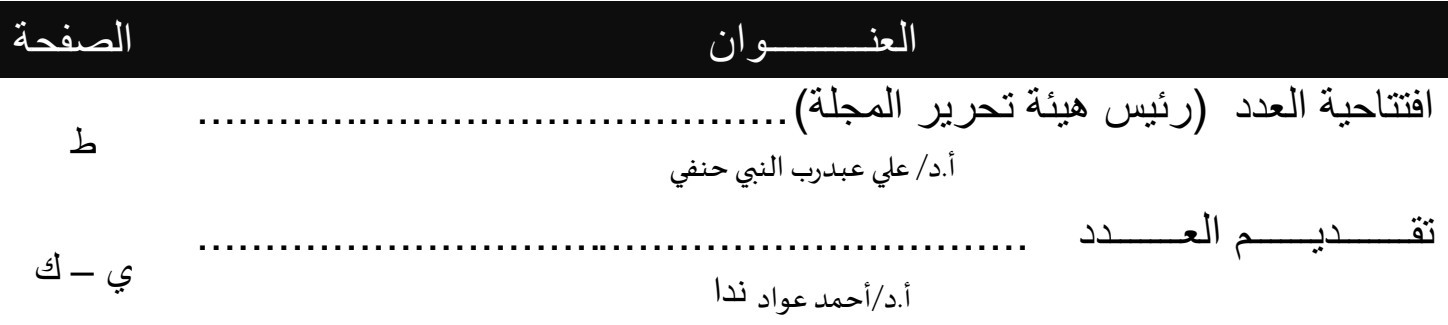

\section{القسم الأول: الابحسبـات}

$r r-1$

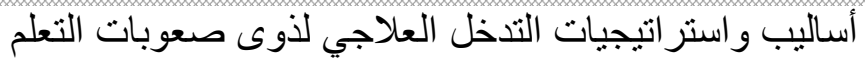
أ.د/ عادل عبد الله محمد \& أ.د/ أحمد أحمد عواد التعل علاد

$\Delta r-r V$ الأسباب المساهمة في حدوث الإعاقة الفكرية بالمملكة العربية السعودية.

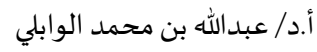

الفهم القرائي و التعبير الكتابي لدى الطلاب الصم الملتحقين بكليات المؤسسة العامة

$-\wedge r$

114

$-114$

$1 \leqslant 1$

$-1 \leqslant \Gamma$

$17 \mathrm{~V}$

$-179$ rYT

$-p^{-k T H}$ TTY للتنريب التقني و المهني في المملكة العربية السعودية "در استة ميدانية" . د/ عثمان بن علي المنيعي \& د/ طارق بن صالح الريس الريس

التفكير الإبداعي و علاقته بالتحصيل الدر اسي لدى طالبات قسم التربية الخاصة في كلية

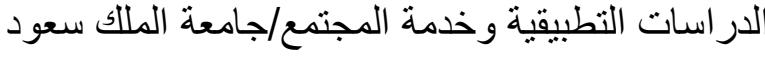

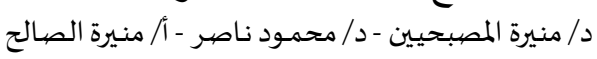

فاعلية برنامج تدريبي مقترح لتنمية الكفايات التدريسية لمعلمي الصم بمدينة عر عر .........

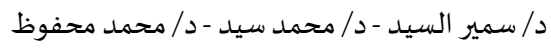

المتغير ات المعرفية لتلاميذ المرحلة الابتدائية ذوي قصور المهار ات قبل الأكاديمية كمؤشر د /فايزة إبراهيم عبداللاه أحمد

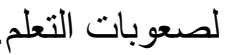

فاعلية برنامج تعليمي للقيم الأخلاقية في تعديل سلوكيات اضطر اب نقص الانتباه وفرط الحركي

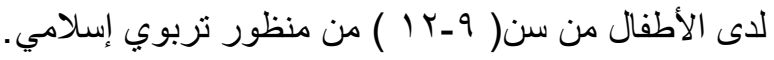

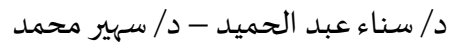




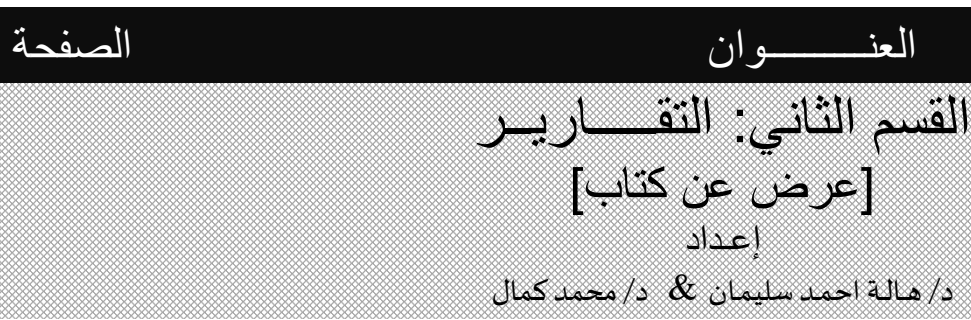

- rา9

rV.

$-Y V$

rVo

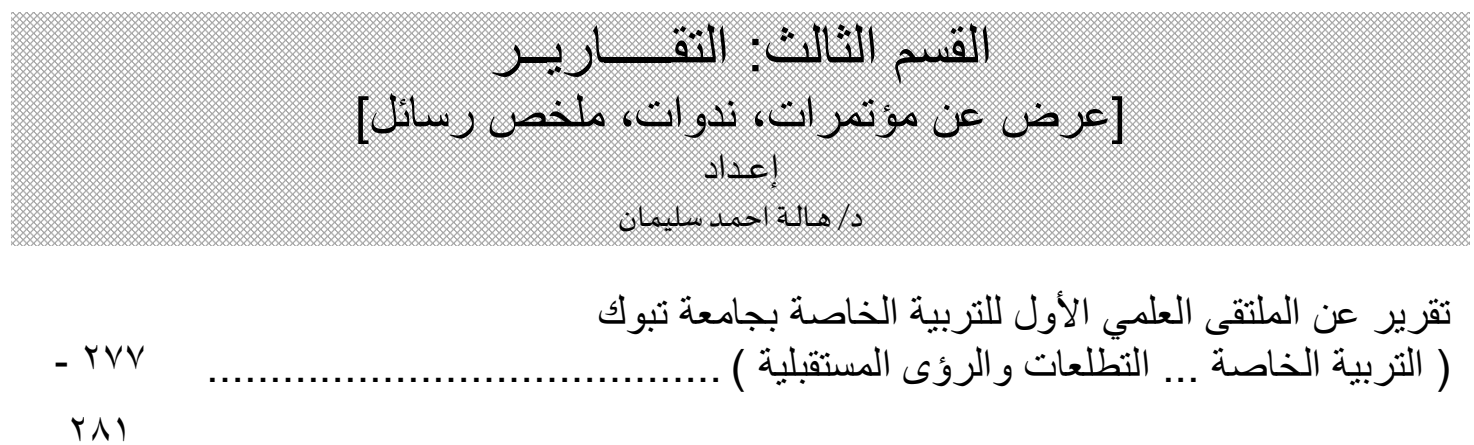

$-r \Lambda r$

تقرير عن رســالـة مـــاجستير بعنـــــان فاعلية برنامج تدريبي لعلاج قصور الانتباه rAO

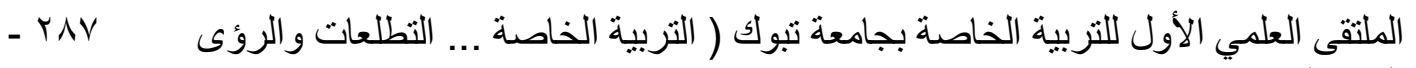
rq. المستقبلية) . 


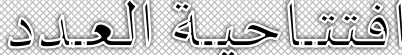

أ.د / عـلى عبــــ رب النـبـي حنــي(*)

بسعد مجلة التربية الخاصة، و التأهيل أن تقدم للبـاحثين أصددق التحيـات، وأعطر هـا، بعد العداء

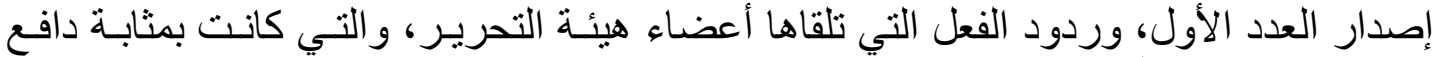

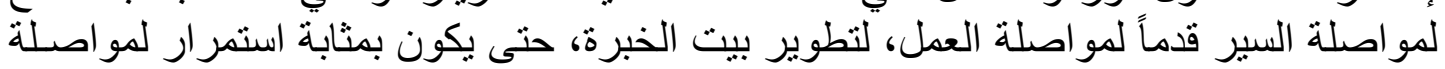

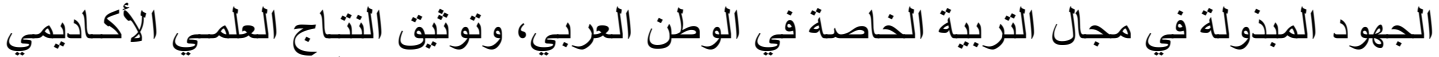

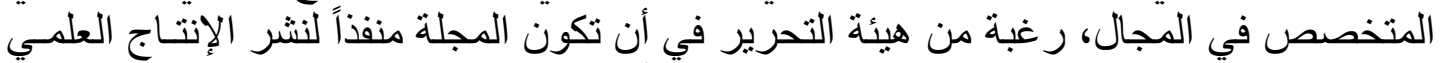

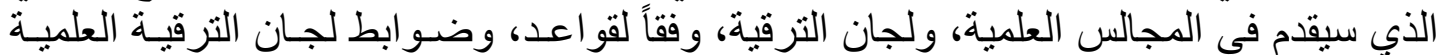

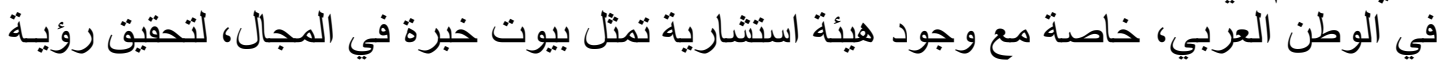

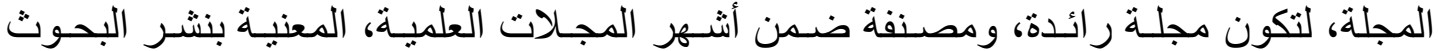
المحكمة في مجال التربية الخاصة، واندة ومصنأنأهيل في قو اعد البيانات العالمية.

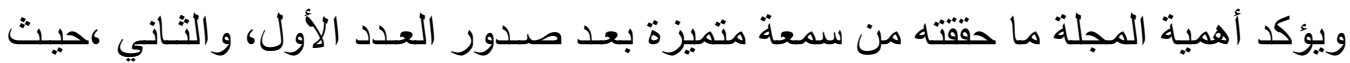

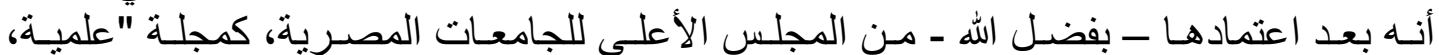

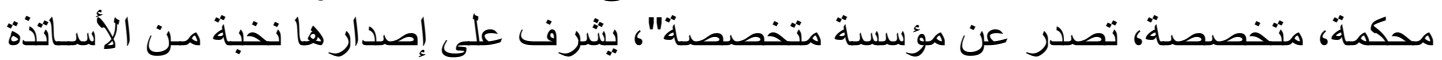

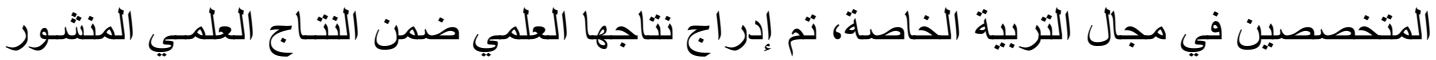

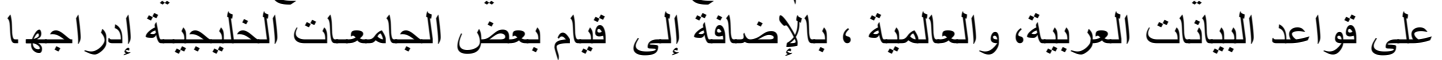
ضمن المجلات التي يوصي بالنشر فيها.

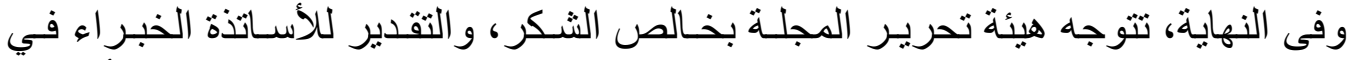

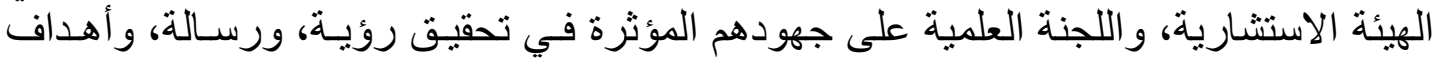

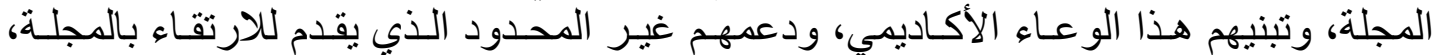
لتصبو إلى مجار اة المجلات العالمية. تحباتي و تقديري 


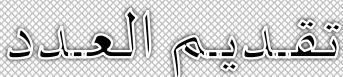

الأستاذ الدكثور / أحمد أحمد عو اد (*)

تحظى التربية الخاصة بمزيد من الاهتمام والدعم على المستويين العربي و الدولي، نظـراً

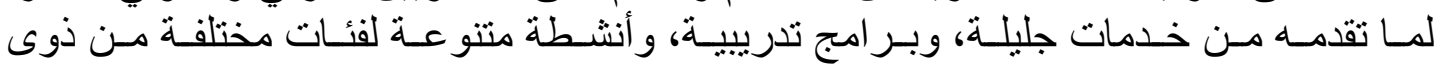

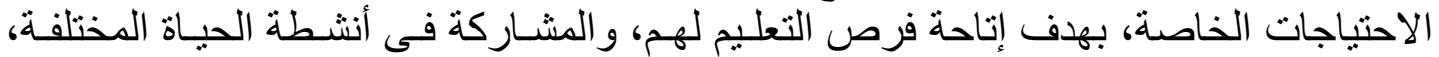

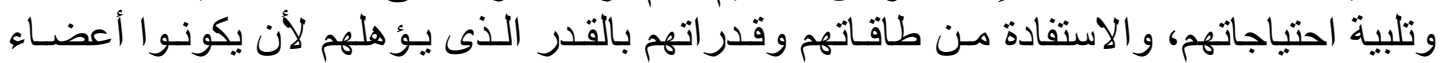

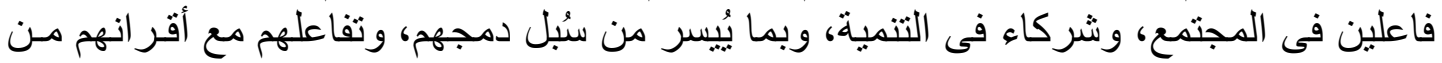

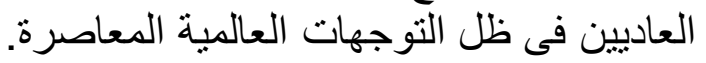

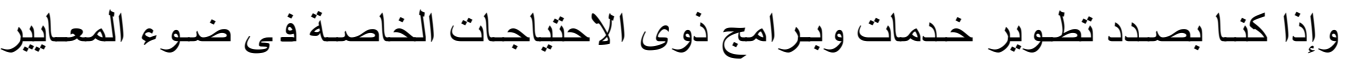

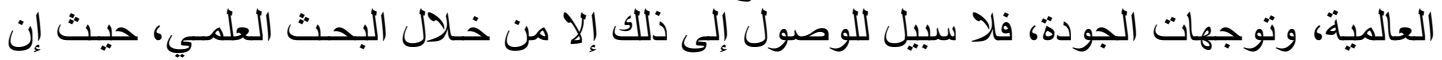
البحث العلمي فى كافة ميادين المعرفة هو قاطرة الدول الدول نحو التقدم، و الرفى.

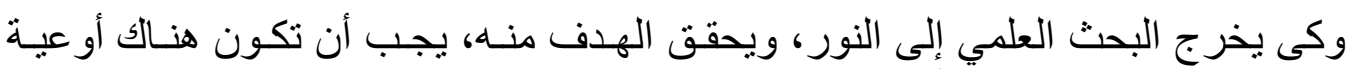

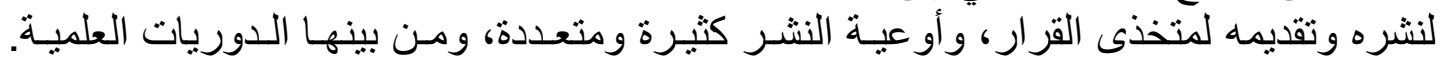

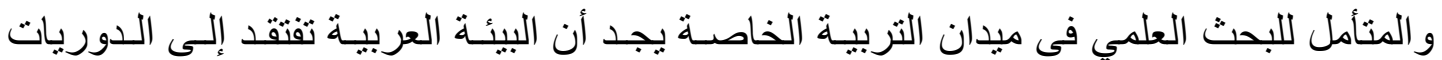

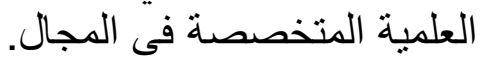

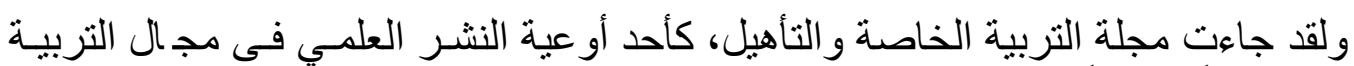

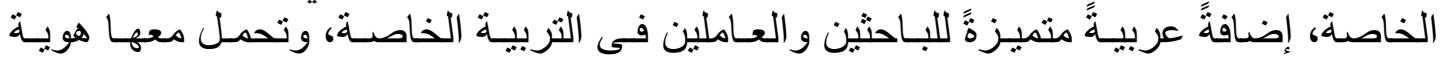

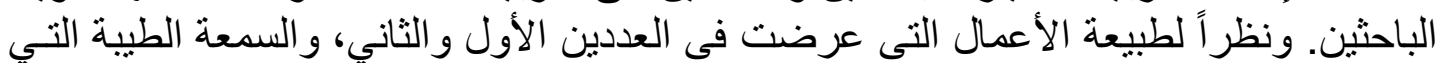

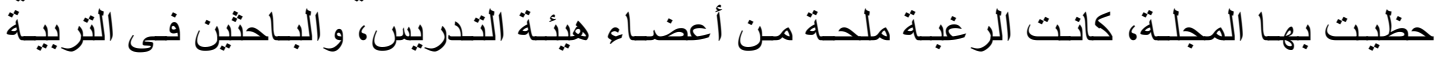

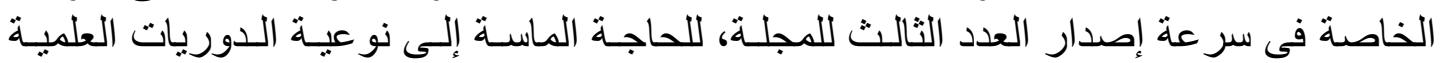

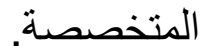

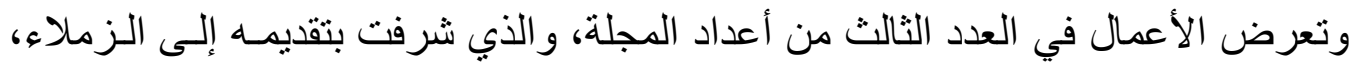

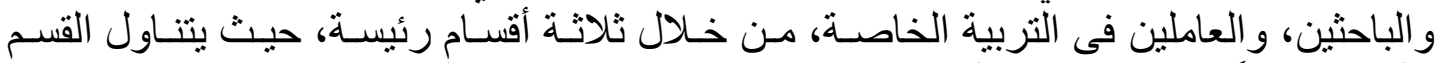

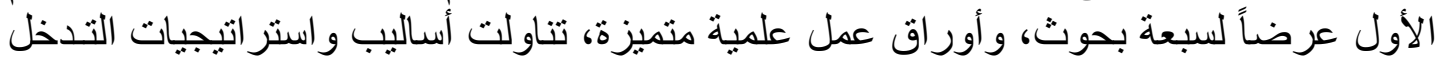

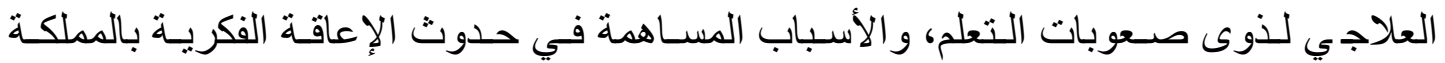

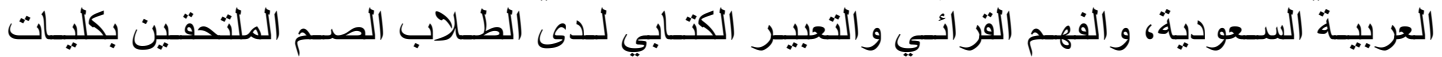

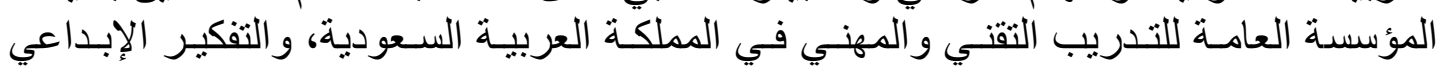

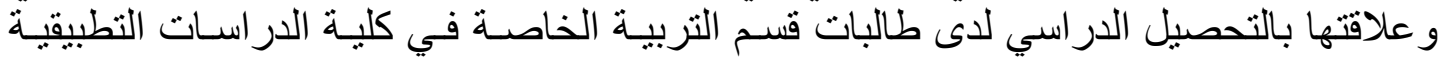

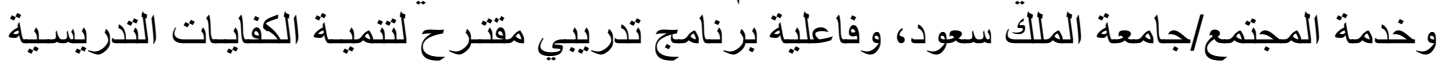

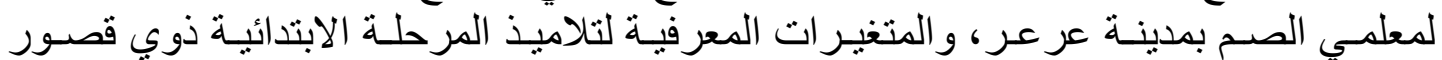

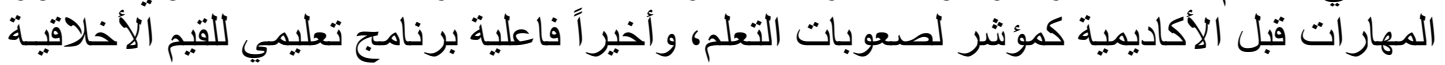

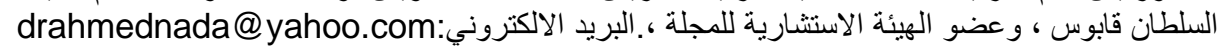


في تعديل سلوكيات اضطر اب نقص الانتباه وفرط الحركي لاى الأطفال من سن ( Y- I ) مـن منظور تربوي إسلامي.

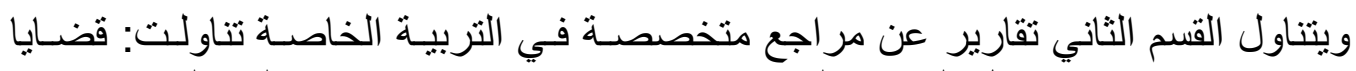

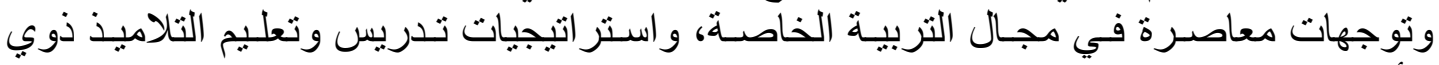

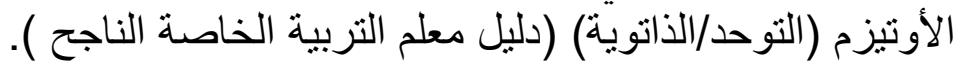

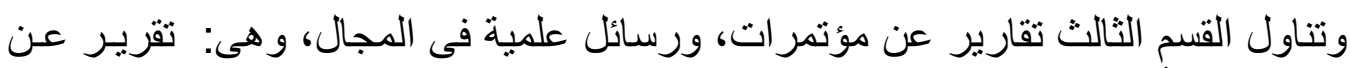

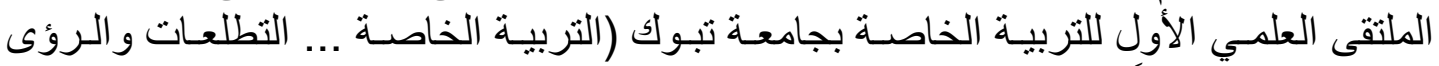

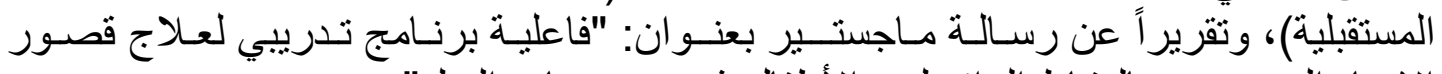

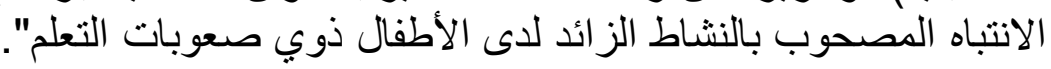

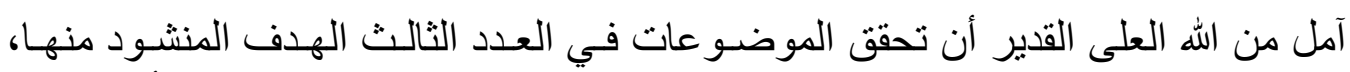

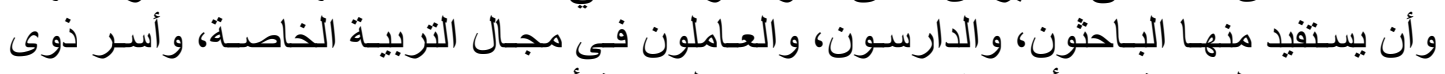

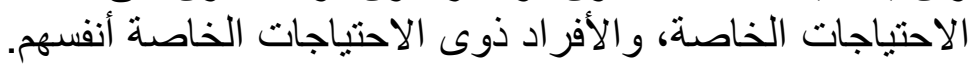

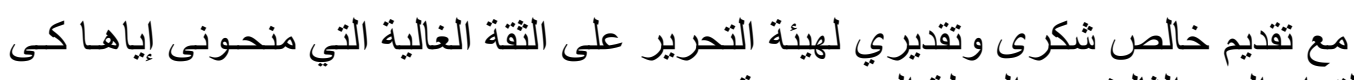
أقدم للقراء العدد الثالث من المجلة المتخصصئ.

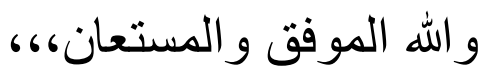

